\title{
MAKNA PUPUH (TEMBANG) DALAM tRADISI RITUAL SANDINGAN MASYARAKAT JAWA KABUPATEN KEDIRI
}

\author{
DHEA ISTIQOMAH', DIAN AGUNG ISNANTO \\ Universitas Muhammadiyah Malang
}

Pertama Diterima: 4 Juni 2018

Bukti Akhir Diterima: 27 September 2019

\begin{abstract}
Abstrak
Tradisi ritual Sandingan merupakan salah satu kebudayaan yang ada di Indonesia dan dilakukan oleh masyarakat Jawa. Pada ritual Sandingan terdapat Pupuh (tembang) yang dilantunkan sebagai alat komunikasi dan pengingat dalam menjalani kehidupan seharihari. Tujuan dari penelitian ini adalah untuk membedah makna Pupuh (tembang) yang terdapat dalam tradisi ritual Sandingan. Penelitian ini penting dilakukan sebab Pupuh (tembang) dalam tradisi ritual Sandingan memiliki makna yang bermanfaat bagi pembaca serta dalam rangka melestarikan tradisi ritual masyarakat Jawa. Metode yang digunakan ialah desktiptif kualitatif dan pendekatan yang digunakan peneliti dalam penelitian ini ialah pendekatan semiotik dengan memanfaatkan teori Roland Barthes. Data dalam penelitian ini berupa diksi Jawa yang dialihbahasakan ke dalam bahasa Indonesia, sumber data penelitian ini adalah hasil penuturan seorang informan yang diprediksi memahami tradisi ritual Sandingan. Teknik pengumpulan data yang dilakukan penulis dalam penelitian ini adalah teknik wawancara, mekanisme analisis menggunakan analisi isi. Pengecekan keabsaan data peneliti menggunakan teknik diskusi dengan ahli dan teman sejawat. Hasil dari penelitian ini menunjukan Pupuh (tembang) yang ada pada tradisi ritual Sandingan dan terdiri dari sepuluh bait, yang mana setiap baitnya memiliki berbagai kandungan manfaat sebagai pendoman hidup manusia.
\end{abstract}

Kata Kunci: tradisi, pupuh (tembang), makna, Jawa.

\begin{abstract}
The tradition of the ritual Sandingan is one of the cultures that existed in Indonesia and performed by Javanese. On the ritual of Sandingan there is a Pupuh (tembang) which is chanted as a tool of communication and reminders in everyday life. The purpose of this research is to dissect the meaning of Pupuh (tembang) which is contained in the tradition of the ritual Sandingan. This important research is done because Pupuh (tembang) in the tradition of the ritual of Sandingan has a meaning that is useful for the reader as well as in order to preserve the tradition of Javanese ritual. The method used is qualitative descriptive and the approach used in this study is the researchers approach semiotic by utilizing the theory of Roland Barthes. The data in this research in the form of diction Javanese translated into the language of Indonesia, data source this study is the result of the utterance of an informant predicted understand the tradition of ritual Sandingan. The technique of data collection conducted in this research is the author of the interview techniques, analysis of mechanisms use content analysis. Validity checking of the data the researchers used the technique discussion with experts and colleagues. The results of this research show the Pupuh (tembang) on the Sandingan rituals and traditions consisting of ten stanzas, in which each temple has a variety of benefits as the content of guidelines of human life.
\end{abstract}

Keywords: tradition, pupuh (tembang), meaning, Java. 


\section{PENDAHULUAN}

Orang Jawa, sejak lahir sebagian besar tumbuh di lingkungan yang mistik mulai dari lingkungan keagamaan hingga pada sosial masyarakatnya yang percaya akan hal-hal goib tidak terlepas dari ritual-ritual yang tak jauh dari persembahan-persembahan atau biasa disebut dengan sajen. Menurut Wahyana (2010:14) bagi orang Jawa upacara tradisi ritual dengan menggunakan sajen (sesaji) adalah peristiwa yang sudah diakrabi sejak manusia Jawa lahir. Setiap orang Jawa yang lahir sudah diperkenalkan dan dibesarkan dengan berbagai macam kebudayaan termasuk kegiatan ritual.

Masyarakat Jawa tidak lepas dengan tradisi ritual, salah satu contohnya ialah ritual Sandingan. Ritual ini dilaksanakan oleh orang Jawa pada saat menjelang bulan puasa, dalam ritual tersebut terdapat banyak sesaji dihidangkan dan setiap sesajinya berfungsi sebagai simbol yang bermakna. Ritual merupakan gudang dari berbagai simbol yang memiliki makna dari sebuah informasi serta dianggap memiliki kredibilitas tersendiri, seperti keterkaitannya terhadap nilai-nilai terpenting dari masyarakat Jawa, Irmasari (2013:5).

Ketika proses tradisi ritual berlangsung, banyak melibatkan berbagai bentuk interaksi dengan memanfaatkan berbagai jenis benda maupun ucapan yang bersifat filosofis. Menurut Rahayu et al (2014:57) dalam tradisi ritual masyarakat Jawa banyak dijumpai penggunaan simbol verbal baik berupa mengucapan kata-kata serta diksi tertentu hingga simbol nonverbal seperti benda, waktu, tata cara, dan tempat yang secara khusus disiapkan serta mempunyai makna.

Dalam tradisi ritual Sandingan tersebut, selain sesaji terdapat juga Pupuh (tembang) yang dilantunkan sebagai pelengkap tradisi ritual tersebut. Tembang merupakan karya sastra lisan masyarakat Jawa. Melalui media tembang tersebut, seorang individu dapat menyuarakan keluh kesah yang ada dalam hati dengan maksud tertentu, hal itu menunjukan tembang sebagai alat untuk berkomunikasi. Tembang merupakan alat komunikasi lisan yang digunakan oleh orang Jawa sebagai bentuk aktualisasi diri, A'yun (2009:9).

Tradisi sastra lisan yang digunakan oleh orang Jawa seperti Pupuh (tembang) merupakan wujud dari pemikiran masyarakat Jawa yang diperoleh dari pewarisan nenek moyang. Leluhur orang Jawa mewariskan sastra lisan tersebut bertujuan sebagai bekal dalam menjalani kehidupan, sebab banyak unsur penting yang perlu ditelusuri secara mendalam terhadap sastra lisan Jawa. Tradisi lisan memposisikan diri sebagai media penuangan gagasan dan kolerasi antara sosio-kultur dalam sebuah kolektif, di dalamnya memiliki berbagai simbol atau kode kekhasan yang kaya akan makna Endraswara (2005:1-3).

Bahasa yang digunakan pada tembang memiliki nilai estetik, sebab penggunaan dan pemilihan bahasa pada tembang dapat mempengaruhi makna yang ada pada tembang tersebut. Menurut Padmosoekotjo dalam Widiyono (1960:5) bahasa dalam sastra Jawa memiliki dua variasi yaitu basa lumrah atau bahasa biasa dan basa endah atau bahasa yang indah.

Bahasa salah satu aspek penting dari sebuah Pupuh (tembang) sebagai sastra lisan, sementara itu tembang memiliki bahasa yang indah dan bermakna. Bahasa merupakan hasil kebudayaan manusia serta sebagai simbol bermakna yang sengaja dihadirkan untuk keperluan manusia dalam kegiatan komunikasi. Bahasa merupakan bagian dari sitem makna yang saling berkolaborasi 
mengkonstruksi budaya masyarakat. Maka dapat dikatakan, bahasa dan manusia dua hal yang tidak mungkin untuk dipisahkan (Setiyadi (2012:4).

Tembang seyogyanya memiliki berbagai macam unsur kebahasaan yang dapat mengkonstruksi tembang menjadi indah. Tembang yang terdapat dalam tradisi ritual Sandingan menggunakan bahasa Jawa santun dan halus. Tembang adalah lirik atau sajak serta mengandung irama dan nada. Tembang umumnya dalam bahasa Indonesia dianggap sebagai sebuah lagu. Endraswara (dalam Gani 2014:43) memaparkan bahwa tembang sebagai sastra lisan berbentuk puisi yang memiliki berbagai aturan. Namun dalam tradisi ritual Sandingan terdapat tembang yang dilantunkan tanpa dinadakan, akan tetapi tujuannya sama yaitu untuk berkomunikasi.

Menurut Manafe (2011:287) komunikasi tersebut bertujuan untuk menunjukan konsistensi mereka terhadap pemberian penghormatan terhadap tradisi yang ada pada keluarga, keagamaan, dan etnik Jawa. Jadi, dapat dikatakan fungsi dari Pupuh (tembang) ialah sebagai alat komunikasi mereka terhadap makhluk baik yang dapat dilihat maupun yang tidak dapat dilihat dengan mata telanjang serta menjadi sarana pemberi wejangan. Pada dasarnya masyarakat Jawa percaya bahwa dunia tidak sekadar dihuni manusia saja. Menurut Setyowati (2007:10) masyarakat masih menilik bahwasannya dunia tidak hanya didiami oleh mahkluk yang dapat dilihat dengan mata telanjang saja, melainkan berbagai makhluk kasat mata.

Selain sebagai alat komunikasi, mereka percaya dalam Pupuh (tembang) memiliki ajaranajaran tingkah-laku berbudi luhur yang dapat dimanfaatkan oleh pelaku tradisi tersebut sebagai tuntunan dalam menjalani kehidupan. Tembang digunakan sebagai sarana memberi wejangan pengingat kehidupan sehari-hari dalam masyarakat Jawa Tarigan dalam Setiyadi (1987:52). Hal itu terjadi karena masyarakat Jawa, pada masa lampau memiliki kepercayaan terhadap mitos-mitos kepada sesuatu hal yang dipercayai mempunyai kekuatan. Menurut Rosyidi (2012:93) orang Jawa sebelum mengenal keagamaan mereka menganut paham animisme dan dinamisme, yaitu percaya terhadap sesuatu hal dan kepada sesuatu hal tersebut mereka membesitkan berbagai permohonan.

Pupuh (tembang) dalam tradisi ritual Sandingan memiliki unsur estetik yang tinggi, terlebih pada wujud dan makna yang dikandungnya. Keterpaduan wujud dalam tembang tersebut memiliki pengaruh terhadap makna yang disajikan. Keterpaduan wujud seperti ini dapat melahirkan makna yang memiliki kandungan nilai maupun norma dalam mempengaruhi kehidupan etnik Jawa.

Pada umumnya masyarakat yang bertempat tinggal di Desa khusunya Kabupaten Kediri masih menggunakan Pupuh (tembang) yang ada dalam tradisi ritual Sandingan untuk memberikan wejangan, selain untuk pelengkap dalam tradisi ritual tersebut. Mereka masih melakukan tradisi ritual Sandingan tersebut karena kepercayaan mereka terhadap makhluk kasat mata yang harus dihormati.

Menurut salah seorang informan yang peneliti wawancarai yaitu Ibu Tutik (46) yang berkediaman di Desa Bendosari Kecamatan Kras, Kab. Kediri, beliau berkata bahwasannya selain melakukan tradisi ritual Sandingan untuk menghormati sanak sodara yang telah tiada, di balik Pupuh (tembang) yang ada didalam tradisi ritual Sandingan tersebut memiliki berbagai manfaat yang dapat dipetik untuk menuntun manusia dalam menjalani kehidupannya. Desa Bendosari, Kecamatan Kras, Kabupaten Kediri. Merupakan suatu Desa di Kab. Kediri, yang masyarakatnya masih melakukan tradisi ritual Sandingan meskipun pelaku tradisi tersebut tidak sebanyak dahulu. 
Hal itu terjadi karena pergeseran budaya dan modernitas dari kota yang mulai merangsek masuk ke desa.

Berdasarkan latar belakang tersebut maka rumusan masalah dalam penelitian ini yaitu, (1) Bagaimana makna Pupuh (tembang) yang dilantunkan dalam prosesi tradisi ritual Sandingan?

Penelitian serupa tentang tradisi ritual Sandingan, juga telah dilakukan oleh sodara Yuyun Setyowati dalam bentuk skripsi dengan judul Tradisi Sandingan Dalam Masyarakat Jawa Di Lumajang. Penelitian yang dilakukan penulis tersebut hanya memaparkan prosesi atau tahapantahapan dalam tradisi Sandingan. Berbeda dengan penelitian yang dilakukan oleh peneliti saat ini adalah untuk membedah kandungan makna terdahap Pupuh (tembang) yang dilantunkan dalam prosesi tradisi ritual Sandingan dalam masyarakat Jawa sebagai bentuk penghormatan dan permohonan yang diucapkan saat melakukan kegiatan tradisi ritual tersebut.

Penelitian mengenai Pupuh (tembang) yang terdapat pada tradisi Sandingan ini juga di rasa penting untuk dilakukan, sebab penelitian terhadap tradisi Sandingan ini masih sedikit peminat khususnya untuk penelitian bagian tahap doanya, sebagian besar peneliti hanya berfokus terhadap tahapan-tahapan prosesi tradisi ritual upacaranya saja. Selain itu penelitian ini dapat dimanfaatkan oleh pembaca sebagai penambah wawasan tentang tradisi ritual orang Jawa.

Dalam penelitian ini penliti menggunakan pendekatan semiotika sebagai upaya dalam membedah makna Pupuh (tembang) yang ada pada tradisi ritual Sandingan, semiotika dipilih karena merupakan kajian ilmu yang digunakan untuk mengungkapkan suatu makna yang ada pada objek tertentu. Semiotika adalah sebuah cabang ilmu yang kajiannya tentang tanda dan segala sesuatunya berhubungan terhadap tanda seperti halnya sistem tanda dan segala proses berkaitan dengan penggunaan atau pemanfaatan tanda Lantowa dalam Zoest (2017:1).

Penelitian ini menggunakan pendekatan semiotika dengan teori Roland Barthes. Semiotika adalah suatu ilmu atau metode analisis untuk mengkaji tanda, di dalam pendekatan semiotika simbol dipahami sebagai suatu lambang yang ditentukan oleh objek dinamisnya dalam artian tanda harus benar-benar diinterpretasi. Dalam hal ini melibatkan unsur dari proses belajar dan tumbuh atau berkembangnya pengalaman serta kesepakatan-kesepakatan yang terdapat dalam lingkungan masyarakat Kurniawan dalam Anugrah (2016:321). Dalam kajian semiotika terdapat dua prinsip sebagai langkah menginterptrestasi objek yaitu, penanda (signifer) dan petandan (signfied) yang mana kedua prinsip tersebut saling berhubungan. Menurut Pardopo (1987:121) sistem tanda memiliki dua prinsip utama yakni, penanda atau yang menandai objek dan petanda atau yang ditandai objek, penanda sendiri merupakan wujud dari tanda, sedangkan petanda merupakan makna tanda.

Asumsi dasar dari teori yang dikemukakan oleh Roland Barthes memiliki tiga inti struktur utama yang ada dalam kajiannya, ketiga struktur inti tersebut antaralain sistem pemaknaan yang pertama disebut sebagai makna denotasi, sistem makna yang kedua dalam kajiannya disebut sebagai makna konotasi, dan yang terakhir Roland menyebutnya sebagai sistem mitos. Menurut Ismujihastuti dalam Dwisthi \& Mahadian (2015:998) sistem makna pertama yaitu denotasi sebagai langkah mengungkapkan suatu makna dari objek yang telah termampang nyata dalam penglihatan manusia, sementara itu konotasi bertugas sebagai pembedah makna tersembunyi di balik tanda maupun simbol yang melekat pada sesuatu objek tersebut. 
Maka pengkajian dilakukan pada tanda yang tersirat bukan berarti kasat mata, berbeda dengan mitos, mitos terdapat pada lingkungan masyarakat melebur menjadi satu dengan kehidupannya sebab pengintrepretasian dalam masyarakat terhadap sesuatu melalui pertimbangan dan menggunakan korelasi antara yang dilihatnya nyata atau denotasi dan tanda seperti apa yang tersirat dalam suatu fenomena tersebut atau disebut sebagai konotasi.

Penggunaan pendekatan semiotika dengan teori Roland Barthes oleh peniliti dalam penelitian Pupuh (Tembang) yang ada pada tradisi ritual Sandingan dimaksudkan untuk mengungkapkan makna yang terdapat dalam Pupuh (Tembang) tersebut.

\section{METODE PENELITIAN}

Penelitian ini menggunakan metode deskriptif kualitatif sebagai metode dalam mengkaji makan dari Pupuh (tembang) yang dilantunkan dalam prosesi ritual Sandingan, sebab metode deskriptif kualitatif berfokus pada huruf bukan angka-ngka. Metode kualitatif merupakan sebuah metode yang dirancang untuk mengkonstruksi sebuah realitas dan sebagai langkah memahami suatu makna yang ada di dalamnya, Somantri (2005:58). Pendekatan yang digunakan penulis dalam penelitian adalah pendekatan semiotika.

Data dalam penelitian ini adalah berupa diksi Jawa yang dialihbahasakan ke bahasa Indonesia. Sumber data dalam penelitian ini adalah teks hasil wawancara yang diperoleh dari penuturan seorang penduduk Desa Bendosari Kecamatan Kras Kabupaten Kediri yang masih melakukan tradisi ritual Sandingan.

Teknik Pengumpulan Data penelitian ini peneliti melakukan wawancara terbuka dengan salah satu informan yang saat ini masih melaksanakan tradisi Sandingan dan diperkirakan memahami tentang Pupuh (tembang) yang ada dalam tradisi ritual tersebut. Informan adalah orang yang diprediksi memiliki pemahaman dan menguasai data, informasi, maupun kebenaran terhadap objek yang diteliti, Bungin (2010:108).

Teknik Analisis data pada penelitian ini menggunakan teknik analisis isi. Adapun tahapan yang dilakukan peniliti dalam menganalisis data, yaitu (1) Mengalihbahasakan teks yang telah dicatat dari bahasa Jawa ke bahasa Indonesia agar lebih mudah dipahami, (2) Membaca kembali Pupuh (tembang) yang telah dialihbahasakan, (3) Mendeskripsikan makna Pupuh (tembang), (4) Menarik kesimpulan.

Sebagai langkah akhir dari penelitian dan untuk memastikan keakuratan data diadakan pemeriksaan keabsahan data. Teknik yang dipakai antara lain (1) ketekunan dalam pengamatan, maksudnya ialah mengamati kembali dengan teliti terhadap data yang telah diperoleh, dan (2) pengecekan sejawat, ialah mengadakan diskusi bersama teman sejawat dan ahli yang diprediksi mampu memahami objek penelitian. 


\section{HASIL PENELITIAN DAN PEMBAHASAN}

Hasil dari wawancara terbuka yang telah dilakukan penulis, terhadap informan yang diprediksi memahami Pupuh (tembang) beserta tradisi ritual Sandingan. Diperoleh sepuluh bait tembang yang dilantunkan dalam tradisi ritual tersebut antaralain.

\section{a. Pupuh (tembang) bait pertama}

Yayi sedaya ingsun,

Lumakua muji gusti,

Kinanthi laku menembah,

Gegulang agama suci,

Lan kena pengaruh muspra,

Dimen ayem urip niki.

Dialihbahasakan ke dalam bahasa Indonesia menjadi;

Adik saudara ku,

Berjalanlah dengan berdoa kepada Allah,

Dengan menjalankan sembahyang,

Belajar agama suci,

Dan jangan terpengaruh hal-hal yang tidak berguna,

Supaya hidupmu sekarang tentram.

Bait pertama Pupuh (tembang) yang dilantunkan dalam tradisi ritual Sandingan memiliki arti sebagai penanda agar kita selalu ingat kepada Sang Pencipta, wujud dari keingatan tersebut dapat berupa memohon apapun yang kita inginkan kepada-Nya bukan kepada hal yang lain. Hal itu ditandai dengan kalimat bahasa Jawa, seperti di bawah ini.

Yayi sedoyo ingsun,

Lumakua muji gusti

Makna Kutipan di atas menunjukan petanda bahwasannya dengan mengucapkan kalimat tersebut kita sudah mengingatkan kepada diri sendiri dan orang sekitar, serta sebagai penanda karena dalam kutipan kalimat tersebut bahasa yang digunakan memiliki makna yaitu, agar senangtiasa ingat kepada Allah SWT. dan di berikan kesajeterahan dalam menjalani kehidupan.

Orang jawa tidak pernah lupa untuk selalu memberi atau mengingatkan sanak sodaranya agar selalu berjalan di jalan yang telah di takdirkan Sang Pencipta. Menurut (Harini, 2012, hal 38) kehidupan manusia di dunia memiliki sifat yang sementara, hal tersebut mendorong masyarakat Jawa untuk selalu mengingatkan kepada orang sekitarnya untuk selalu memohon dan menjalankan perintah Allah dalam upaya mengejar kesejahteraan hidup.

\section{b. Pupuh (tembang) bait kedua}

Katur sanggyaning para kadang,

Kepareng hamba amiwir,

Pagedhonganing piwulang,

Saking sinerat kitab suci Sang Maha linuwih,

Kang samiya amituhu,

Lamun manggya lepat,

Linuberna ingaksami,

Mring sagung para kadang mitra sagotrah. 
Dialihbahasakan ke dalam bahasa Indonesia menjadi;

Untuk saudara-saudara ku semuanya,

Perbolehkanlah saya untuk berbicara,

Pentingnya nasehat,

Dari Tuhan Yang Maha Kuasa,

Yang ditulis dalam kitab suci, yang harus ditaati,

Walaupun tidak sengaja melakukan kesalahan (dosa),

Berilah maaf sebesar-besarnya,

Kepada saudara-saudara ku semuanya.

Bait kedua Pupuh (tembang) yang ada dalam tradisi ritual Sandingan tersebut menandakan bahwa manusia dalam menjalani kehidupan harus memiliki pedoman yang mampu menyelamatkan diri sendiri, baik lahir dan batin serta dunia dan akhirat. Sebab manusia memiliki keterbatasan akal sehingga tidak luput dari kesalahan, oleh karenanya manusia perlu peraturan dari Sang Pencipta, pedoman yang telah diberikan oleh Allah kepada manusia ialah kitab suci.

Hal itu ditandai dengan kutipan

Pagedhonganing piwulang,

Saking sinerat kitab suci Sang Maha linuwih,

Kang samiya amituhu,

Lamun manggya lepat

Maksud dari kutipan tersebut adalah sebagai petanda bahwasannya, Allah SWT. telah menurunkan kitab suci bagi umatnya, untuk dijadikan pedoman atau tuntunan kehidupan yang wajib untuk ditaati oleh seluruh umat dan dilaksanakan dengan penuh keikhlasan.

Manusia dalam menjalani kehidupan harus memiliki pendoman, hal itu dimaksudkan untuk menjaga nilai budaya yang telah diajarkan oleh leluhur dan agama serta sebagai pengendali hasrat diri dalam bertindak. Menurut Theodore (dalam Sartini, 2009: 30) dalam budaya terdapat nilai yang bersifat abstrak, hal tersebut dapat dijadikan pedoman dan menjadi prinsip umum dalam mengambil tindakan serta bertingkah laku dalam masyarakat yang berkaitan erat dengan emosional.

\section{c. Pupuh (tembang) bait ketiga}

Manungsa urip nggilut,

Becik lamun tansah ngangkah emut,

Mawas dhiri mekak rupa tindak juti,

Memayu hayuning kalbu,

Bisa mbrastha lampah bobrok.

Dialihbahasakan ke dalam bahasa Indonesia menjadi;

Manusia hidup untuk mencari ilmu (belajar),

Lebih baik apabila,

Selalu mengingat arah yang baik,

Yaitu mawas diri dengan menahan wajah (hawa nafsu) dan bertindak yang baik,

Berkelakuan baik dalam hati,

Dapat menumpas kelakuan yang rusak. 
Maksud dari Pupuh (tembang) bait ketiga yang dilantunkan dalam tradisi ritual Sandingan adalah menandakan sebagai makhluk hidup khususnya manusia untuk (manut) taat kepada Sang Pencipta, melakukan sholat dengan di dasari dari hati yang suci, jujur, serta sabar. Umat manusia disarankan agar selalu meningkat kemawasan diri, beserta dengan niat dalam menjalani kehidupan secara (alon-alon) pelan-pelan, tujuannya untuk menghindarkan diri dari hal-hal yang kurang baik.

Hal tersebut ditandai dengan kutipan bahasa Jawa.

Manungsa urip nggilut,

Becik lamun tansah ngangkah emut,

Mawas dhiri mekak rupa tindak juti

Makna Kutipan Pupuh (tembang) tersebut sebagai petanda yang memiliki arti untuk mengingatkan kepada umat manusia yang tinggal di bumi untuk senangtiasa menjaga diri, menanamkan perilaku yang baik yang bertujuan untuk menghindari perilaku buruk. Tidak hanya itu, kutipan tersebut turut mengingatkan manusia dalam mencari ilmu untuk mempertimbangkan dari sisi kebaikan.

Hal tersebut sesuai dengan tujuan hidup orang Jawa yaitu, hidup damai dan tentram dalam bermasyarakat. Menurut (Sartini, 2009, hal 38) manusia Jawa memiliki kebutuhan untuk hidup secara manusiawi, maksud dari manusiawi adalah hidup dalam kerukunan menghadirkan sifatsifat baik dan menjauhkan diri dari sifat tercela.

\section{d. Pupuh (tembang) bait keempat}

Pan ana silih bebasan,

Padha sinauwa ugi,

Lara sajroning kapenak,

Lan suka sajroning prihatin.

Lawan ingkang prihatin,

Mapan suka ing jronipun,

Iku den sinauwa.

Lan mati sajroning urip,

Ingkang kuna pan mangkono kang den gulang.

Dialihbahasakan ke dalam bahasa Indonesia menjadi;

Terdapat ibarat bahasa,

Bersama-sama dengan belajar juga

Sakit ketika dalam sehat

Serta suka ketika dalam kesengsaraan

Bersama suka saat mengalami penderitaan

Disitulah terdapat kesenangan

Dan hal demikian pelajari pula

Yang di zaman lalu memang yang seperti ini telah dilatih.

Maksud dari Pupuh (tembang) bait keempat yang terdapat dalam tradisi ritual Sandingan ialah menandakan dalam hidup manusia harus ingat kepada tuhan, baik dalam keadaan sulit maupun saat mendapatkan musibah harus bersyukur kepada Sang Pencipta. Sebab Allah masih 
memperhatikan hambanya dan Dia tidak akan memberikan cobaan melampaui batas kemampuan hambanya.

Dalam keadaan susah maupun senang kita harus selalu bersyukur atas nikmat yang telah diberikan, hal tersebut ditandai dengan kutipan di bawah ini.

Lara sajroning prihatin

Mapan suka ing sinauwa

Makna dari kutipan tersebut adalah sebagai petanda yang mengingatkan kepada umat manusia agar selalu bersyukur terhadap apa yang telah diberikan oleh Allah, baik dalam keadaan senang maupun duka. Pemberian senang dan duka tersebut bukanlah wujud kemarahan Allah, melainkan memberi peringatan kepada hambanya agar selalu berjalan sesuai dengan ajaran agama.

Sifat menerima tersebut sesuai dengan sikap hidup orang Jawa yang (neriman) menerima apapun yang telah diberikan oleh Sang Pencipta, baik dalam hal yang baik maupun hal yang buruk. Menurut De Jong (dalam Muslich, 2004, hal 208) orang Jawa memiliki empat sifat utama yaitu, pertama rela, memiliki rasa ikhlas dalam menjalani kewajibannya sebagai hamba kepada tuhannya, kedua neriman, tidak memiliki niatan memiliki kepunyaan orang lain, ketiga sabari, memiliki arti kuat dalam menghadapi cobaan yang diberikan, iman dan mental kuat, keempat budi luhur, artinya jika seorang individu hidup dengan kabaikan ingat selalu dan menjaga kehidupannya niscaya akan sentosa kehidupannya.

\section{e. Pupuh (tembang) bait kelima}

Gegarane urip amrih basuki,

Udinen dimen dadi widada,

Yuwana rahayu kabeh,

Utama lampahipun,

Budi luhur sabar taberi,

Rumeksa kekadangan,

Udur datan purun,

Kinanthen rasa katresnan,

Unggah-ungguh rumeksa ing samukawis,

Nuhoni mring agama.

Dialihbahasakan ke dalam bahasa Indonesia menjadi;

Landasan hidup supaya hidup sejahtera,

Carilah supaya menjadi selamat,

Bahagia selalu, sifat yang utama,

Adalah budi pekerti yang baik sabar hati-hati,

Mempunyai rasa persaudaraan, tidak suka bertengkar,

Dan mempunyai rasa kasih sayang,

Semua kelakuan,

Berpedomana pada hukum agama.

Maksud dari Pupuh (tembang) bait kelima yang terdapat dalam tradisi ritual Sandingan ialah menandakan hidup manusia harus sejahterah dengan ditandai terdapatnya rasa aman, damai, serta tentram, dengan memiliki ketiga rasa tersebut seorang individu akan dapat 
merasakan kebahagiaan. Sejahtera sendiri memiliki arti hidup bercukupan mulai dari sandang, pangan, serta papan. Kemudian disusul dengan diterimanya diri dalam hidup bermasyarakat, tidak hanya sekedar mencari kesejahteraan hidup, namun dengan mematuhi perintah-Nya, Sang Pencipta setiap hari memberikan perintah kepada umat manusia agar senangtiasa menjalani perintah dan menjauhi larangannya, contohnya seperti berprilaku mencuri, mencela, berdusta, dan lain sebagainya.

Kehidupan yang sejahtera ditandai dengan kutipan.

Gegarane urip amrih basuki,

Budi luhur sabar taberi,

Udur datan purun,

Unggah-ungguh rumeksa ing samukawis,

Nuhoni mring agama.

Makna kutipan Pupuh (tembang) di atas sebagai petanda bahwasannya manusia khususnya orang Jawa haruslah memiliki rasa persaudaraan, saling menghormati, tidak suka membuat keributan semua hal yang dilakukan ini semata-mata hanya untuk mencari kesajetaraan dalam hidup berlandaskan agama.

Hal tersebut sejalan dengan sikap kehidupan orang Jawa, yang mana mayoritas orang Jawa lebih fokus terhadap ketenangan jiwa dan terhindar dari masalah-malasah duniawi. Menurut (Sartini, 2009, hal 32) kelompok masyarakat Jawa dalam menjalani kehidupan sehari-hari, sangat memperhatikan sikap kehidupan yang sederhana, penuh dengan rasa tanggung jawa, menghormarti perasaan orang yang ada disekitarnya, berbudi luhur, dan senangtiasa bersikap tenggang rasa. Memiliki sikap seperti ini semata-mata hanya untuk mengejar kesajehteraan hidup.

\section{f. Pupuh (tembang) bait keenam}

Aja dumeh maksih mudha, Anuraga mung sakarsa pribadi,

Gumendhung tur,

Kumalungkung,

Lir angemperi jagad,

Tebah jaja sapa

Sira sapa ingsun,

Rahwana kang kauja,

Temahan tuna pribadhi.

Dialihbahasakan ke dalam bahasa Indonesia menjadi;

Jangan bertingkah laku sombong ketika masih muda,

Raga itu hanya keinginan pribadi,

Bertingkah laku tinggi hati,

Sombong,

Seperti ingin menguasai dunia,

Dengan menepuk dada siapa saya siapa kamu,

Golongan rahwana (buta/kemaksiatan) yang selalu dituruti,

Yang hanya membuat rugi diri sendiri. 
Maksud dari Pupuh (tembang) bait keenam dalam tradisi ritual Sandingan ialah menandakan pada diri manusia janganlah memiliki sifat tinggi hati atau sinonim bahasa Indonesianya sombong. Sifat sombong yang paling dusta ialah sombong kepada Sang Pencipta dengan tidak menuruti perintah dan tidak menerima kebenaran serta memiliki hati dan kepala batu. Oleh sebabnya Yang Maha Kuasa memberikan anjuran pada manusia agar untuk senangtiasa menjaga pikiran, hati, dan perilaku dalam kehidupan. Hal itu bertujuan untuk menjauhkan individu dari sifat-sifat yang tidak terpuji seperti sombong karena akan menjerumuskan diri sendiri kepada kerugian. Sifat untuk tidak sombong ditandai dengan kutipan di bawah ini.

Aja dumeh maksih mudha, Anuraga mung sakarsa pribadi

Temahan tuna pribadhi

Makna dari kutipan di atas adalah petanda jika manusia memiliki sifat sombong akan merugikan diri sendiri, sifat sombong hanyalah keinginan diri individu dan akan dibenci orang, serta hidupnya akan susah seperti Rahwana dalam pewayangan.

Dalam cerita pewayangan tokoh Rahwana dikenal dengan sifat tidak terpuji seperti sifat sombong, sifat tersebut hanya akan bertahan di awal saja dan menuju keterpurukan di akhir. Menurut (Muslich, 2004, hal 205) dalam pandangan Jawa kehidupan seperti cokromanggilingan, bagaikan roda berputar ada saatnya di atas adapula saatnya di bawah, oleh sababnya dalam pandangan hidup orang Jawa telah tertanam tiga sifat terpuji sebagai upaya menghindari sifat tercela antaralain bersabar dalam menghadapi segala cobaan, tidak asal memutuskan suatu tindakan tetapi dipikirkan terlebih dahulu, dan selalu berhati-hati dalam bertindak.

\section{g. Pupuh (tembang) bait ketujuh}

Elinga sira manungsa,

Ngelingana anggonmu sholat ngaji,

Mumpung sira durung lampus,

Katekan Malaikat,

Dhutane kang Maha Kuwasa satuhu,

Amisah sukma lan raga,

Sewu lara sasi siji.

Dialihbahasakan ke dalam bahasa Indonesia menjadi;

Ingatlah kamu manusia,

Ingatlah kamu pada sholat dan ngaji,

Sebelum kamu belum mati,

Kedatangan Malaikat,

Utusan yang sebenarnya dari Tuhan Yang Maha Kuasa,

Memisahkan sukma dan raga,

Seribu sakit menjadi satu

Maksud dari Pupuh (tembang) bait ketujuh dalam tradisi ritual Sandingan tersebut menandakan, bahwasannya makhluk yang bernafas di muka bumi ini akan mati pada waktunya, termasuk manusia yang akan dipanggil kepada-Nya tidak memandang umur. Oleh karenanya Sang Pencipta memerintahkan kita untuk melaksanakan sholat, hal tersebut bertujuan untuk 
bekal kebahagiaan di akhirat khelak. Sholat dalam agama Islam merupakan tiang agama. Sang Pencipta mengingatkan manusia akan kematian dengan ditandai kutipan di bawah ini.

Eling siro menungso,

Mumpung siro drung lampus,

Makna dari petanda kutipan di atas tersebut bahwasannya manusia hanya ciptaan Allah yang dalam kehidupannya harus menyembah dan senangtiasa ingat dan menjalankan kewajibannya terhadap ketentuan-Nya, wujud dari mengingat dan menyembahnya dengan cara melaksanakan perintahnya seperti sholat serta mengaji. Aktivitas tersebut wajib dilakukan sebelum ajal menjemputnya, dan didatangi oleh Malaikat yang diberitugas oleh-Nya untuk menghampiri dan mengambil hamba-Nya.

Sebagai individu yang religius, orang Jawa memiliki keyakinan dan kepercayaan terhadap keberadaan Tuhan yang harus disembah dan di patuhi segala perintahnya seperti sholat dan mengaji, kegiatan tersebut di dasari dari perasaan religi maupun emosi keagamaan. Menurut (Sabatri, 2012, hal 2) orang Jawa meyakini adanya Sang Penguasa Alam yang mengatur segala kehidupan yang ada di bumi, oleh karenanya mereka taat melaksanakan berbagai kewajiban dalam agama yang mereka yakini memiliki sifat ritual hingga seremonial. Maksudnya ialah dalam kehidupan sehari-hari tidak terlepas dari tuntutan yang harus dilaksanakan dan bersifat religius serta agamsi.

\section{h. Pupuh (tembang) bait kedelapan}

Yektinipun ibadah sholat puniku,

Pinarya panyegah,

Laku dosa lan ngapusi,

Dhuhur 'Asyar Mahgrib Isya', lan Shubuhnya.

Lan poso ing wulan Ramadhan.

Dialihbahasakan ke dalam bahasa Indonesia menjadi;

Sebenarnya ibadah sholat itu,

Sebagai alat untuk penyegah,

Untuk bertingkah laku yang melanggar perintah Allah bertindak dosa dan menipu,

(Sholat 5 waktu) tersebut adalah Dhuhur 'Asyar Mahgrib Isya', dan Shubuhnya)

Dan jangan lupa puasa di bulan Ramadhan.

Maksud dari Pupuh (tembang) bait kedelapan dalam tradisi ritual Sandingan tersebut penanda untuk menuntut umat muslim untuk mempringati hari besarnya, yaitu perjalanan seorang panutan umat Islam nabi dengan segala rasa syukur karena memperoleh perintah khusus untuk wajib melaksanakan sholat lima waktu diantaranya sholat Subuh, Dhuhur, Asyar, Maghrib, serta Isya'. Semua itu dilakukan dalam rangka menjauhkan diri dari perbuatan tercela dan disusul dengan puasa di bulan yang penuh berkah yaitu, Ramadhan. Perintah untuk melaksanakan sholat dan puasa sebagai upaya pencegahan dari perbuatan tercela ditandai kutipan di bawah ini.

Sira tan tahan panggodha

Pinarya penyerah 
Makna dari kutipan di atas ialah sebagai petanda Sang Pencipta telah memberikan perintah terhadap manusia agar menghindar dari sifat sombong dengan cara mengerjakan sholat lima waktu yaitu, Subuh, Dhuhur, Ashar, Magrhib, serta Isya' dan menjalankan puasa di bulan Ramadhan, untuk menghindarkan dirinya dari bertingkah laku yang masuk kerana menentang perintah-Nya.

Bagi orang Jawa memberi pengingat kepada sesama dapat melalui karya sastra yang diyakini memiliki nilai kebenaran berdasarkan budaya keagamaan yang dianut, serta diwariskan oleh leluhur atas karya tesebut. Menurut (Haedar, 2016, hal 3) di samping melestarikan budaya, orang Jawa pada dasarnya tetap mengapresiasi nilai etika serta mengamalkan ajaran Islam. Syariat Islam, khususnya dalam kegiatan religius. Bagi masyarakat Jawa, melaksanakan kewajibannya sebagai umat Islam, khususnya kegiatan sholat tidak sekadar melaksanakan rukun Islam melainkan untuk media menggapai kesempurnaan dalam mengenal Sang Pencipta.

\section{i. Pupuh (tembang) bait kesembilan}

Panyuwun ku miring illahi robbi,

Tahun anyar tan ana rubella,

Kalisa sambakalane,

Datan ana dahuru, katentreman langit lan bumi,

Sirna sakehing kala,

Rahmad te Hyang Agung,

Wus lingsir rong ewu pitulas,

Tahun anyar madhangi sagung dumadi,

Rahayu kang pinanggya.

Dialihbahasakan ke dalam bahasa Indonesia menjadi;

Permohonan doaku kepada Tuhan Yang Maha Esa,

Tahun yang baru tidak ada rintangan,

Lancar tanpa halang rintang,

Tidak ada kerusuhan,

Ketentraman di langit maupun di bumi,

Hilang karena banyaknya rintangan,

Rahmadnya dari Tuhan Yang Maha Kuasa,

Telah hilang ditahun dua ribu tujuh belas,

Tahun yang baru memberi cahaya yang cerah untuk semua mahkuk ciptaan Tuhan,

Sehingga ketentraman yang didapat.

Maksud dari Pupuh (tembang) bait ke kesembilan yang terdapat dalam tradisi ritual Sandingan adalah menandakan dalam memohon segala apapun yang diinginkan dengan cara berdoa. Berdoa kepada Sang Pencipta dapat digolongkan ke dalam pengaduan diri kepada Allah dengan meminta pertolongan maupun kemudahan dalam menghadapi permasalahan yang dihadapi di tahun yang akan datang.

Allah memerintahkan kepada seluruh hambanya agar selalu meminta pertolongan kepadaNya dengan cara beroda, hal itu ditandai dengan kutipan.

Panyuwun ku miring Illahi Robbi

Katrentaman langit lan bumi,

sirna sakehing kala 
Makna dari kutipan di atas adalah sebagai petanda bahawasannya melalui kegiatan berdoa dimaksudkan untuk meminta segala pertolongan dan berkah di tahun baru Islam dapat dilewati dengan lancar tanpa ada berbagai bentuk penghalang, dengan melakukan kegiatan berdoa berkah akan turun di tahun berikutnya. Ketentreaman yang ingin dicapai terelasiasikan.

Berdoa adalah kegiatan yang pada umumnya dilakukan oleh umat manusia dari berbagai aliran keyakinan, khususya bagi orang Jawa berdoa merupakan bentuk dari sebuah permohonan kepada Sang Illahi. Oleh karena mereka bersyukur dengan apa yang telah diberikan kondisi hidup yang sedemikan adanya, selain itu Sang Illahi lebih paham dengan apa yang dibutuhkan umatnya. Menurut Endraswara (dalam Haedar, 2012, hal 5) Sang Pencipta maha mengetahui perbuatan umatnya baik maupun buruknya, seluruh peristiwa yang terjadi di alam semesta ini telah diketahui-Nya.

\section{j. Pupuh (tembang) bait kesepuluh}

Njeng Gusti aparing sabda,

Nyuwuna adrenging ati,

Kowe bakal kaparingan,

Golekana aneng ngendi,

Kowe bakal amanggih,

Lan thothok-thothoka pintu,

bakal kawenganan Lawang,

Allah mahatresna asih,

Tansah njagi lan njegeni umat-Nya.

Dialihbahasakan ke dalam bahasa Indonesia menjadi;

Allah $S W T$. bersabda "memintalah sesuai keinginan hati mu,

(Permintaan) kamu pasti bakal terkabul,

Mencari dimanapun kamu pasti akan ketemu,

Dan ketuklah pintu,

Pasti akan dibukakan pintu,

Allah Maha Penyayang,

Yang selalu menjaga dan melindungi umat-Nya.

Maksud dari Pupuh (tembang) bait kesepuluh yang terdapat dalam tradisi Sandingan adalah menandakan bahwa Sang Pencipta alam semesta akan selalu menjaga dan melindungi hambahambanya tanpa terkecuali dan tidak terbatas waktu, segala bentuk kebesarannya telah ditunjukan dengan menerima keadaannya hamba-Nya dengan berbagai bentuk dan keadaan. Seperti yang telah dijanjikannya, mintalah sesuai dengan keinginan hati, dengan begitu Allah akan mewujudkan, serta di saat kamu mengetuk pintu di tempat dan kondisi apapun akan dibukakan pintu tersebut.

Maksud dari dibukakan pintu ialah pintu kerahmatan dari sang Illahi.Allah akan selalu menjaga dan menerima umatnya dalam kondisi apapun ditandai dengan kutipan di bawah ini.

Njeng Gusti pangeran paring sabda,

Nyuwun adrenging ati. 
Makna dari kutipan di atas adalah sebagai petanda bagi umat manusia diharapkan agar selalu ingat kepada Allah, sebab Allah akan senangtiasa menjaga dan memberikan berbagai hal yang baik untuk umat-Nya. Mintalah segala keinginan kepada-Nya bukan ke yang lain niscaya Dia akan mengabulkan dan melindungi hambanya dengan penuh kasih sayang.

Kelompok masyarakat Jawa memiliki kecenderungan percaya akan hal-hal yang berbau gaib yang menurut mereka dapat dimintai sesuatu, kepercayaan tersebut dianggap sebagai hal yang lumrah sebab kehidupan masyarakat Jawa dahulu terkenal akan animisme dan dinamismenya. Akan tetapi orang Jawa masih memiliki keyakinan bahwasannya hidup di dunia telah diatur oleh Sang Pencipta, maka ia akan berserah diri kepadanya. Menurut Indrasuari (2012:22) orang Jawa dalam menganut aliran animism dan dinamisme, tetap memiliki dan harus mengakui bahwasannya terdapat zat yang memiliki kuasa penuh atas kehidupan di dunia ini yaitu, Allah.

\section{Makna Denotasi Pupuh (tembang) yang ada dalam tradisi ritual Sandingan}

Pupuh (tembang) yang terdapat dalam tradisi ritual Sandingan, memiliki bentuk bahasa Jawa halus dan indah. Pemilihan bahasa Jawa yang halus tersebut bertujuan untuk lebih mudah dilantunkan dan dipahami oleh pendengar selain sesuai dengan pewarisan leluhur yang menggunakan bahasa Jawa halus, Pupuh (tembang) tersebut memiliki jumlah keseluruhan sepuluh bait, pengucapan tembang dilakukan dengan alur yang runtun dan pelan-pelan. Pada tembang ini menurut informan yang telah diwawancarai oleh penulis Ibu Tutik (46), beliau berkata pada umunya tembang dilantukan dengan cara dinyanyikan.

Hal itu senada dengan Dewi (2018:2) bahwa dalam melantunkan tembang, lebih mementingkan unsur suara sebagai hiburan dan menyanyikannya tidak secara runtun tetapi dibagi dalam beberapa bagian. Pelantunan tembang dilakukan dengan menggunakan irama yang santai, halus, dan ditambahkan kata yang membuat pendengar mengingat tentang kehidupan, akan tetapi pada kesempatan tradisi ritual Sandingan tidak dinyanyikan melainkan diucapkan seperti biasanya. Hanya saja pelafalan tiap baitnya berbeda-beda guna memberikan penekanan makna dan irama agar nyaman didengar serta maksud tujuan makna tersampaikan.

\section{Makna Konotasi Pupuh (tembang) berkaitan dengan mitos yang ada dalam tradisi ritual Sandingan}

Makna dari Pupuh (tembang) yang terdapat dalam tradisi ritual Sandingan, dalam ritual ini disetiap bait yang dibacakan memiliki makna yang dapat diambil. Makna yang tersirat dalam setiap baitnya mengajarkan bahwa setiap umat manusia harus bersyukur dengan apa yang diberikan Allah $S W T$. baik itu diberikan keburukan maupun kesenangan, umat manusia haruslah bersyukur. Seperti pada bait keempat

Pan ana silih bebasan,

Padha sinauwa ugi,

Lara sajroning kapenak,

Lan suka sajroning prihatin.

Lawan ingkang prihatin, 
Yang dalam bahasa Indonesia berarti

Terdapat ibarat bahasa,

Bersama-sama dengan belajar juga

Sakit ketika dalam sehat

Serta suka ketika dalam kesengsaraan

Bersama suka saat mengalami penderitaan

Dari kutipan diatas dapat dilihat bahwa pupuh (tembang) bait keempat mengandung makna keadaan apapun yang diberikan Allah $S W T$. merupakan hal yang paling baik menurut-Nya untuk umatnya, segala sesuatu itu harus disyukuri dan tidak lupa untuk selalu beribadah sebagai wujud rasa syukur terhadaphal apapun yang telah terjadi. Segala seuatu yang diinginkan mintalah kepadaNya karena Allah SWT. tahu semua yang diharapkan umatnya namun diberikan sesuai dengan apa yang terbaik menurutnya untuk umatnya tersebut.

Semua yang kita jalani didunia ini dilihat serta dipantau oleh Allah $S W T$., karena itu haruslah kita terus berusaha untuk beribadah serta memohon apa yang di inginkan kepada Allah $S W T$. bukan kepada yang lainnya (patung, pohon, dll). Seperti dalam kutipan tembang ketujuh berikut ini

Eling siro menungso,

Mumpung siro drung lampus,

Yang dalam bahasa Indonesia berarti

Ingatlah kamu manusia,

Ingatlah kamu pada sholat dan ngaji,

Dari kutipan diatas dapat dilihat bahwa pupuh (tembang) bait ketujuh mengandung makna saat memiliki keinginan apapun mintalah kepada Allah Swt. dengan cara sholat, ngaji, dan berdoa agar yang diharapkan bisa tercapai ataupun akan digantikan dengan sesuatu yang lebih indah untuk umatnya. Ketika umat manusia menjalankan perintahnya Allah Swt. akan memberikan ganjaran yang setimpal untuk ibadah yang dilakukannya selama hidupnya didunia.

Allah tidak akan ingkar dengan apa yang dia janjikan kepada umatnya yang mau taat kepada ajaran yang dia berikan. Sementara itu, masyarakat Jawa merupakan kelompok masyarakat yang terbentuk dari perkumpulan komunitas tradisional, yang terdiri dari beberapa aspek antaralain mitos, religi, magi, serta ilmu pengetahuan. Aspek-aspek tersebut saling bekesinambungan dan menjadi sebuah tradisi ritual yang hidup berakar dari pewarisan leluhur dari nenek moyang kepada generasi selanjutnya.

Mitos yang berasal dari zaman dahulu kala, mayoritas orang Jawa masih meyakini keberadaannya. Menurut Muslich (2004:210) dalam mitologi Jawa, religiuitas dan hal mistik menjadi tolak ukur mengenai pandangan kehidupan masyarakat Jawa yang selanjutnya diwujudkan dengan berbagai macam bentuk simbol tertentu. Pada umumnya orang Jawa saat menyuarakan gagasan maupun pesan, memiliki kecenderungan menggunakan bahasa simbol dengan mempertimbangkan rasa serta sikap sopan santun, berdasar hal inilah simbol dapat ditelaah makna yang terdapat di dalamnya.

Masyarakat Desa Bendosari, Kecamatan Kras, Kabupaten Kediri, memiliki kepercayaan terhadap tradisi ritual yang telah diwariskan oleh leluhur mereka, dengan melaksanakan kegiatan 
yang penuh akan simbol-simbol tersebut, mereka beranggapan bahwasannya dalam tradisi ritual tersebut memiliki kekuatan magis yang dapat memberikan mereka ketentraman hidup. Menurut Ibu Tutik (46) salah seorang pelaku tradisi ritual Sandingan, beliau percaya terhadap tradisi ritual masyarakat Jawa tersebut dapat dipetik pelajaran hidup yang telah diwariskan leluhurnya.

Anggapan tersebut dirasa dapat kita yakini, sebab bila diperhatikan dalam Pupuh (tembang) yang ada pada tradisi ritual Sandingan terlepas dari proses ayau tahap-tahap ritual itu, mengajarkan kepada kita bahwasannya hidup harus beserah diri kepada Sang Pencipta. Selain itu mitos yang terkandung dalam tradisi ritual Sandingan menurut informan yang telah diwawancarai, jika saat tradisi itu dilakukan tetapi tidak melantunkan Pupuh (tembang) maka akan sia-sia, sebab bagian terpenting dari ritual ini adalah melantunkan tembang yang berisi pengingat jika tidak dilantunkan, maka harapan-harapan yang diinginkan untuk di tahun selanjutnya yang akan datang tidak terkabul. Tidak hanya itu, seusai melantunkan tembang menurut informan yang diwawancari penulis, beliau mengaku setelah melatunkan tembang merasa seperti merasakan kehadiran kerabat sanak sodara datang menghampirinya. Sesaji yang telah dihidangkan berupa kopi akan diminumnya, hal itu terbukti menurut penuturannya saat menghidangkan kopi tersebut dengan keadaan kopi yang utuh, namun ketika pagi dilihatnya kopi tersebut tidak utuh kembali.

\section{PENUTUP}

Sandingan merupakan salah satu tradisi ritual yang ada di kalangan masyarakat Jawa. Tradisi ritual tersebut berisikan berbagai bentuk sesajen mulai darai buah-buahan, makanan pokok, dan minuman-minuman, selain sesajen dalam bentuk fisik terdapat juga lantunan kata-kata yang berfungsi sebagai petuah atau wejangan pengingat dalam menghadapi permasalahan kehidupan.

Masyarakat Jawa, khususnya yang bertempat tinggal di Desa Bendosari masih melaksanakan aktivitas ritual Sandingan meskipun jumlah pelaku tradisi tersebut tidak sebanyak dahalu, bagi orang yang masih melakukan kegiatan ini karena mereka memiliki kepercayaan bahwasannya dengan kegiatan ritual Sandingan dapat mempererat tali silahturami. Pupuh (tembang) yang ada pada tradisi Sandingan ini memiliki makna yang baik untuk digunakan maupun diteruskan oleh generasi penerus, sebab dalam Pupuh (tembang) memiliki nilai kearifan lokal yang diwariskan secara turun-temurun oleh leluhur. 


\section{DAFTAR PUSTAKA}

A'yun, Kurrota. (2009). SINTREN Sebuah Analisis Tembang dalam Kesenian Tradisional Sintren. Skripsi. Semarang: Universitas Diponegoro Semarang.

Anugrah, Diana. (2016). Analisis Semiotika Prosesi Pernikahan Adat Jawa "Temu Manten" Di Samarinda. Jurnal Ilmu Komunikasi, 4(1). Samarinda: Universitas Mulawarman.

Bungin, B. (2007). Penelitian Kualitatif, Komunikasi, Ekonomi, Kebijakan Publik, dan Ilmu Sosial Lainnya. Jakarta: Kencana Prenada Group.

Dewi, Shintia. (2018). Nilai Didaktis Pada Tembang Dolanan Anak Berbahasa Jawa Di Desa Banyumas Kecamatan Stabat Kabupaten Langkat. Skripsi. Medan: Universitas Negeri Medan.

Gani, H. A. Ramlah. (2014). Kualitas Ciptaan Puisi Siswa Sebagai Bahan Pembelajaran Bahasa dan Sastra Kelas VII Di SMPN 5 Mataram Pada Semster Genap Tahun Ajaran 2012/2013. Tesis. Mataram: Universitas Mataram.

Haedar, Aly M. (2016). Pergeseran Pemaknaan Ritual Merti Dusun Studi Atas Ritual Warga Dusun Celengan Tuntang Semarang. Al-A'raf: Jurnal Pemikiran Ilsam dan Filsafat, 13(1). Semarang: Universitas Wahid Hasyim Semarang.

Harini, Ninik. (2012). Makna Simbolis Srimpi Lima Pada Upacara Ruwatan Di Desa Ngadireso Poncokusumo Malang. Jurnal Bahasa, Sastra, dan Pengajaran, 40(1). Malang: Universitas Negeri Malang.

Indrasuari, A. F. (2012). Kepercayaan Pedagang terhadap Wong Pinter dalam Menunjang Usaha Dagang di Pasar Bintoro Demak. Solidarity: Journal of Education, Society and Culture, (1)1. Semarang: Universitas Negeri Semarang.

Ismujihastuti, Dwisthi, dan Mahadian. (2015). Representasi Wanita Dalam Sampul Album Raisa (Analisis Semiotik Roland Barthes Terhadap Sampul Album Raisa Andriana "Raisa" Dan "Heart To Heart"). eProceedings of Management, 2(1). Bandung: Universitas Telkom.

Kadarisman, AE. (2009). Dari Etnopuitika Ke Linguistik: Menampilkan Potret Lain Bahasa Jawa. Karya Dosen Fakultas Sastra. Malang: Universitas Negeri Malang.

Manafe, Yermia Djefri. (2011). Komunikasi Ritual pada Budaya Bertani Atoni Pah Meto di TimorNusa Tenggara Timur. Jurnal ASPIKOM-Jurnal Ilmu Komunikasi, 1(3), 287-298. Prodi Ilmu Komunikasi. Universitas Pembangunan Nasional "Veteran" Yogyakarta.

MC Giri, Wahyana. (2010). Sajen dan Ritual Orang Jawa. Yogyakarta: Penerbit Narasi.

Muslich, M. (2004). Pandangan Hidup dan Simbol-Simbol Dalam Budaya Jawa. Millah: Jurnal Studi Agama, 3(2). Jakarta: Universitas Indonesia.

Pradopo, DR. (1987). Pengkajian Puisi. Yogyakarta: Gadjah Mada University Press. 
Rahayu, dkk. (2015). Model Pewarisan Nilai-Nilai Budaya Jawa Melalui Pemanfaatan Upacara Ritual. Jurnal Ilmu Komunikasi (JIK), 12(1). Sukoharjo: Universitas Veteran Bangun Nusantara.

Rosyidi, AW. (2012). Doa Dalam Tradisi Islam Jawa. El-Harakah, 14(1). Malang: UIN Maulana Malik Ibrahim Malang.

Sabatri, Widyabakti. (2012). Makna Simbolis Motif Batik Busana Pengantin Gaya Yogyakarta. Laporan Penelitian. Yogyakarta: Universitas Negeri Yogyakarta.

Sartini, W. N. (2009). Menggali Nilai Kearifan Lokal Budaya Jawa Lewat Ungkapan (Bebasan, Saloka, dan Pribahasa). Jurnal Ilmiah Bahasa dan Sastra, 5(1). Fakultas Sastra. Universitas Eirlangga.

Setiyadi, DBP. (2010). Wacana Tembang Macapat Sebagai Pengungkap Sistem Kognisi dan Kearifan Lokal Etnik Jawa. Kajian Linguistik dan Sastra, 22(2). Klaten: Universitas Widya Dharma Klaten.

Somantri, GR. (2010). Memahami metode kualitatif. Hubs-Asia Makara, Sosial Humaniora, 9(2). Jakarta: Universitas Indonesia

Sutrisno, Mudji, dan Hendar Putranto. (2005). Teori-teori Kebudayaan. Yogyakarta: Kanisius.

Tarigan, HG. (1987). Pengajaran wacana. Bandung:Angkasa.

Van Zoest. (1993). Semiotika: Tentang Tanda, Cara Kerjanya dan Apa yang Kita Lakukan Dengannya. Jakarta: Yayasan Sumber Agung.

Widiyono, Yuli. (2013). Nilai Pendidikan Karakter Tembang Campursari Karya Manthous. Jurnal Pendidikan Karakter, 2(2). Purworejo: Universitas Muhammadiyah Purworejo.

Zainuddin dan Ansari. (2013). Analisis Ideologi Dalam Teks Upacara Melengkan Budaya Etnik Prespektif Semiotika Sosial. Jurnal Bahasa, 22(2). Medan: Universitas Negeri Medan. 